\title{
The Importance of the Role of Women Ulama as the Effort to Actualate the Message of Islam to the Value of Equality
}

\author{
Dewi Avivah \\ Pascasarjana Universitas Islam Negeri Walisongo Semarang, Indonesia \\ email:avivahdewi@gmail.com
}

\begin{abstract}
Islam is a gender-just religion so that in the dissemination of its values, genderfair spaces and opportunities are also needed. The purpose of this study is to provide understanding and understanding to the reader that in realizing a gender-just environment, religion is an important slice that needs to be considered. Islam has agreed to create a gender-just order, and it has been stated in the verses of the Koran. This research method uses qualitative research, sourced from reading material and supported by implementation pictures as supporting data. The results showed that the presence of female clerics was very important. Islam has conveyed Islamic teachings by realizing gender justice so that resistance to patriarchal culture in Indonesia can be carried out with the presence of female ulama to understand that women also have human potential so that they can be said to be worthy as scholars. The limitation of this research is that the author is a little complicated in compiling the historical sequence of the presence of women ulama until their existence today. The lack of data sources that the author must obtain is still rare especially in research about Women Ulama as part of the struggle for gender equality.
\end{abstract}

Keywords: Female Cleric, Gender Fair, Islamic Message

\begin{abstract}
ABSTRAK
Islam merupakan agama yang adil gender, sehingga dalam penyebaran nilainilanya diperlukan ruang-ruang dan kesempatan yang adil gender juga. Tujuan penelitian ini adalah untuk memberikan pemahaman dan pengertian kepada pembaca bahwa dalam mewujudkan lingkungan yang adil gender, agama merupakan irisan penting yang perlu diperhatikan. Islam telah sepakat untuk mewujudkan tatanan yang adil gender, hal itu telah disampaikan di dalam ayatayat Al-Quran. Metode penelitian ini menggunakan penelitian kualitatif, yang
\end{abstract}


bersumber pada bahan bacaan dan didukung dengan gambar pelaksaan sebagai data pendukung. Hasil penelitian menunjukkan bahwa kehadiran ulama perempuan adalah hal yang sangat penting. Islam telah menyampaikan ajaranajaran Islam dengan mewujudkan keadilan gender sehingga perlawanan terhadap budaya patriarki di Indonesia dapat dilakukan dengan kehadiran ulama perempuan sebagai pemberian pemahaman bahwa perempuan juga memiliki potensi kemanusiaan sehingga bisa dikatakan layak sebagai ulama. Keterbatasan pada penelitian ini adalah penulis sedikit kerumitan menyusun runtutan sejarah kehadiran ulama perempuan sampai eksistensinya pada hari ini. Minimnya sumber data yang harus didapatkan oleh penulis, karena masih jarang yang meneliti tentang Ulama Perempuan sebagai bagian dari perjuangan kesetaraan gender.

Kata Kunci: Adil Gender, Pesan Islam, Ulama Perempuan

\section{INTRODUCTION}

Islam, a friendly religion to all humans on earth, is vital to discuss especially regarding the values. As a Muslim, understanding and learning Islamic values is an obligation that can be disseminated to Muslims or other humans. The Quran in Arabic has many messages and commands for Muslims to carry out their obligations. Interpreting and understanding the messages contained in the Qur'an can be done easily through several ways including reading and studying the interpretations. We need to know that the interpretations in the Al-Quran have various interpreters, so as academics, we need to find the meaning of interpretation that is most friendly to human values so that in its actualization, the benefits are more than the disadvantages.

In the perspective of Islam, everything created by Allah SWT is based on their respective natures. Islamic thinkers interpret qadar in the Qur'an with the measurements, the attributes that Allah SWT has set for everything, and it is called fate. Thus, men and women as individuals and genders have their own nature. Sheikh Mahmud Saltut said that the human nature between men and women is different, but Allah SWT inevitably bestows potential and abilities on women as he has bestowed them on men (Kasmawati, 2013, Vol 1, No 1: 59-60).

In Indonesia, we need to know that the patriarchal culture is still influential. It ultimately affects the mindset of the people who are predominantly religious. In Islam in particular, the mention of ulama is always pinned to men's figures, not women. This is what causes gender equality fighters to need to reinterpret the meaning of the ulama themselves. The concept of ulama in the Qur'an is the plural form of the word alim which means "knowing or knowing."

Therefore, ulama can be interpreted as a person or group of people who have a broad and deep level of Islamic understanding accompanied by sincerity and honesty in doing (Juhari, 2018, Vol. 1, No. 2: 25). we see that there is no requirement for a scholar only from men. What needs to be addressed here is the reinterpretation of the ulama themselves and efforts to fight for gender equality, namely that women also have the same $p$ otential and opportunity to become ulama. 
Women in this civilization are very rarely, if not forbidden, to be in the position of making decisions, elaborating, and implementing religious laws. In addition to the rights that have been given to women, a woman has an essential role in influencing public decisions or policies of Islamic society. Among them are Khadijah, Fatima, Aisyah, and others. They are seen as women who have specific capacities and ideals. Their opinions and thoughts are in line with the opinions and thoughts of men, and they also have an essential position in the early development of Islam (Zahara, 2019, Vol 6, No 2: 101).

So, looking at the background above, the researcher feels the need to examine the role of female clerics. The value of equality that Islam teaches is that all creatures, both male and female, in the eyes of Allah are the same and what makes the difference is their piety. Therefore, the researcher will examine how the role of Ulama Women in actualizing the message of Islam on the value of equality.

\section{METHOD}

This type of research uses qualitative research. According to Creswell, qualitative research is a type of research that explores and understands the meaning in several individuals or groups of people originating from social problems. In this study, the patriarchal culture, which is still very strong, is part of the social problem. In addition, in Indonesia, the mention of ulama tends to refer to men so that women who can become ulama are inconsiderable. Researchers took data through written sources such as books, journals, and other reading materials. In addition, researchers also added several pictures for supporting data to the object of research. So, looking at the background above, the researcher feels the need to examine the role of female clerics. The value of equality that Islam teaches is that all creatures, both male and female, in the eyes of Allah are the same and what makes the difference is their piety. Therefore, the researcher will examine how the role of Ulama Women in actualizing the message of Islam on the value of equality.

\section{RESULTS AND DISCUSSIONS}

\subsection{Understanding of Scholars}

Rusjdi Ali Muhammad mentioned several general requirements that a scholar must have, including mastering the Koran and hadith perfectly, knowing things related to ijma' and qiyas so that he does not issue a fatwa that is contrary to the rules of Islamic law, mastering Arabic, ushul figh, mastering matters relating to maqasid al-Shari'ah in establishing law (Rusjdi, 2003, Jakarta: 7576).

Since 14 centuries ago, the Koran has discussed the existence and grouping of scholars clearly and straightforwardly. This grouping is intended so that the Islamic community is not mistaken in following them as torchbearers of truth. The Qur'an clearly explains two concepts, namely: First, scholars who are imaged as knowledgeable people know the truth and power of Allah and are committed to obeying, submitting, and only fearing Allah alone. Such concept derives from the meaning of verse 28 in Surah al-Fathr.

Secondly, the Qur'an also hints at the existence of the concept of ulama apart from the letter Asyu'ara verse 197, which means: Isn't it (sufficient) proof for them that the scholars of the Children of Israel know it? Tabatai concluded that what is meant by the Ulama of the Children of Israel are 
people who have extensive knowledge but do not accept the Qur'an as a truth (Juhari, 2018, Vol. 1, No. 2: 26).

\subsection{Equality in Islam}

Islam does not distinguish between rights and obligations that exist in human anatomy. Rights and obligations are always the same in the eyes of Islam for the two different anatomies. Islam puts forward the concept of justice for anyone and anyone regardless of their gender. Islam is a religion that has freed the shackles of the tyranny of slavery, equality of rights and has never prioritized and featured only one anatomical community. Islam is present as a religion that spreads love for everyone (Kasmawati, 2013, Vol 1, No 1: 56).

Islam is a system of life that leads humans to understand the reality of life. Islam is also a global order revealed by Allah as Rahmatan Lil Alamin. So it is a logical consequence that Allah's creation, namely men and women who have a mission as Caliph fil Ardh, must save and prosper nature, and develop awareness of saving human civilization. Thus, women in Islam have a comprehensive role and equal dignity as servants of Allah and carry out the same mandate as men.

Departing from the above position, Muslim women have a very strategic role in educating people, improving society, and building civilization, as has been done by the Shahabiyah in bringing people who lived in their time to civilization excellence. They play a role in their society with a high intention to optimize all their potential so that we do not find one side of all aspects of their lives neglected. They play a role in every time, space, and level of their lives (Kasmawati, 2013, Vol 1, No 1: 62).

In Islam, the basic principles regarding humanity and women's human rights and equal opportunity to serve are clear and unequivocal, even though natural biological differences are obstacles to getting the same rights. As a result of biological differences, functional differences arise. For example, in life called a married couple, in each position, there are different functions (Ermagusti, 2011: 188-189).

There is no difference between men and women in the human capacity as a servant. Both have the same potential and opportunities to become servants of the idea. The ideal servant is the people who are "pious." There is no gender difference to achieve the degree of piety. The specialties that Allah has given to men, because men are protectors for women, all this does not cause men to be the prominent servants in the sight of Allah SWT. These advantages are given to men in their capacity as members of society who have more social and public roles than women. In their capacity as servants, men and women each receive an award from God according to their level of dedication (Ermagusti, 2011: 191-192).

\subsection{Female Clerics in Indonesia and Their Urgency}

The Indonesian Women's Ulama Congress (KUPI) at the Kebon Jambu Islamic Boarding School, Ciwaringin, Cirebon, on 24-27 April 2017, was a historic moment for the successful Indonesian Muslim women's movement. More than 700 people attended the congress. They come from various organizational backgrounds, provinces, cultures, ethnicities, languages, and religious sects. Some participants even came from sixteen countries in Asia, Africa, and America. They are activists who fight for gender equality and justice. 
This Congress of Women's Ulama in Indonesia is the culmination of a series of activities and years of struggle by social organizations working to achieve gender equality and justice. This congress began with a study of Syarh Uqud al-Lujain fi Bayan Huquq az-Zaujan, by Sheikh Nawawi al-Bantani by the Yellow Book Study Forum (FK3). This study focuses on takhrij (assessment) of the hadiths contained in the Islamic boarding school book, namely from the "sanad" (transmission) aspect, not from the "matan" (content) side. This study took place at Gus Dur's house every month for three years. Buya husein read the book, then the participants discussed it.

Interestingly, the study results were later translated into "A new face of husband-wife relations by FK3, with an introduction by KH. Mustofa Bisri, or who is familiarly called Gus Mus. Next, Himpunan Rahima, an NGO that focuses on educational work and Islamic information center for gender equality and justice. It was founded among others by Mother. Mrs. Shinta Abdurrahman Wahid, K.H Muhyiddin Abdusshomad, Dr. Azyumardi Azra, and KH. Hussein Muhammad.

Next up is the Fahmina Institute, founded in 2000 by KH. Husein Muhammad, Dr. Affandi Mochtar, Marzuki Wahid, MA, and Dr. Faqihuddin Abdul Qadir. This institution later became a center for Islamic studies for justice and humanity as well as strengthening community autonomy, including activities for a gender series of Islamic perspectives, studies on democracy, pluralism, and human rights for the cadres of female pesantren leaders (Husein, 2020, Yogyakarta: 11-15).

During that time, Alimat was established in Jakarta. Alimat means female clerics, scholars, scientists, and the like. It includes female scholars from the center for gender studies in Islamic higher education and Islamic socio-religious organizations. From here, they agreed to strengthen the existence of women clerics. Until the convening of the Indonesian Women's Ulema Congress, which has four main objectives, namely: (1) Recognizing and confirming the existence and role of women ulama in the history of Islam and the Indonesian nation. (2) Opening a meeting room for women in the country and the world to share their experiences on women's empowerment and social justice in the context of growing Islamic, national, and humanitarian values. (3) Building shared knowledge about women's ulema and their contribution to the advancement of women and human civilization. (4) Formulating fatwas and religious views of Indonesian female ulama on contemporary issues in the perspective of Islam rahmatan lil alamin.

The Indonesian Women's Ulamas Congress produced a pledge for women called the Kebon Jambu Pledge. It is clearly stated that: First, women are human beings who have all human potential as men through mind and body. Second, throughout the Islamic history of the Prophet Muhammad, women scholars have existed and played a fundamental role in forming Islamic civilization. However, their existence and role have been marginalized by history built unilaterally over centuries. Third, female clerics, along with male clerics, are heirs of the Prophet Muhammad SAW who carried out the mission of monotheism. Fourth, like male scholars, female scholars are responsible for carrying out prophetic missions to remove all forms of tyranny from fellow creatures on any basis. Fifth, as part of the Indonesian nation, female clerics have rights and obligations to realize the ideals of the nation and state.

For Kyai Husein Muhammad, the Kebon Jambu Pledge is a declaration about the re-existence of female ulama. Women scholars have actually existed and played an active role in social, cultural, economic, and political spaces throughout history and made valuable contributions to Islamic civilization and the world in various fields of knowledge and science (Husein, 2020, Yogyakarta: 16). 
Photo of the Indonesian Women's Ulama Congress in 2017

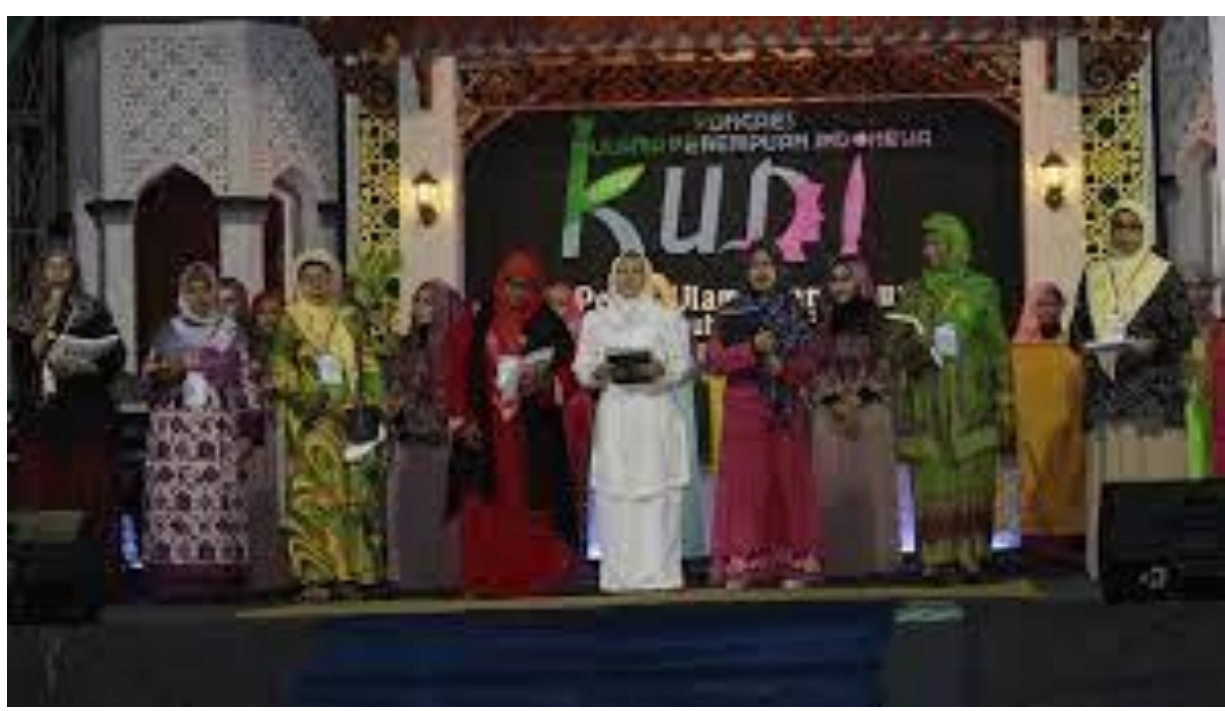

One of KUPI's efforts in spreading the values of equality is through the "Ngaji

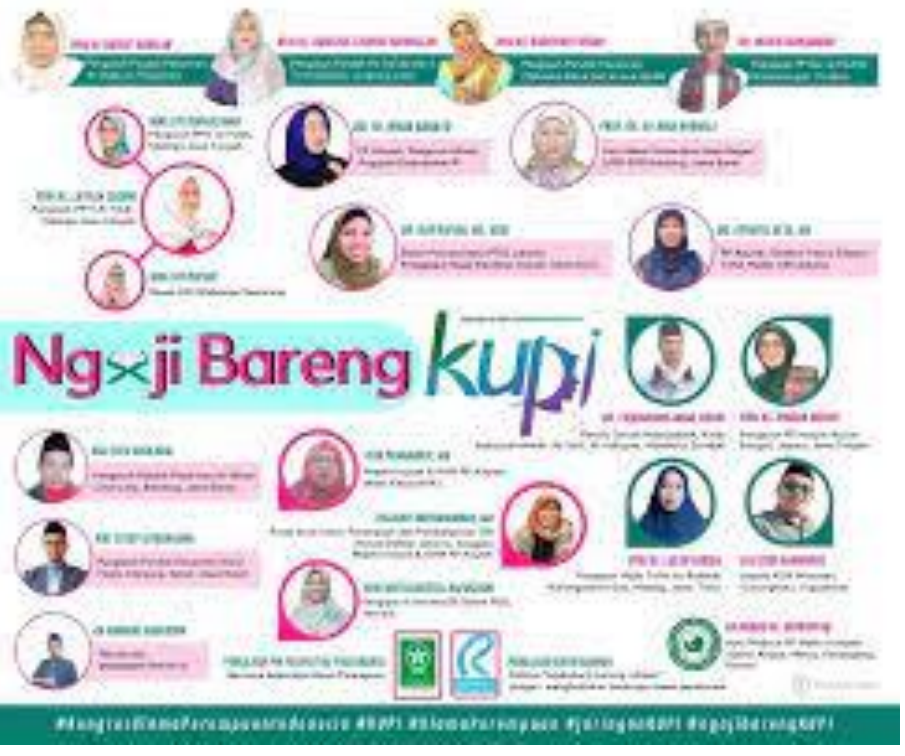

Together with KUPI" program

KUPIPEDIA, launched on November 26th, 2021

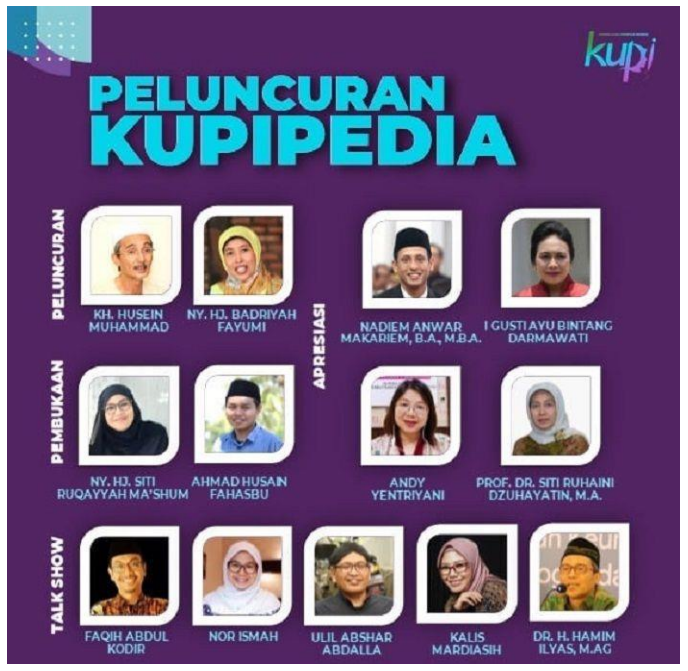


KUPIPEDIA is a digital encyclopedia that contains all documents, information, and knowledge about the KUPI (Congress of Indonesian Women Ulama), which will continue to be developed in accordance with the development of the data itself. All entries on Kupipedia are contributions from institutions and individuals who are members of the KUPI Network.

Through the history of the presence of the Women's Ulama Group in Indonesia, we can see that the value of equality, especially in religious spaces, is still tough to actualize. The presence of KUPI is part of an effort to realize the value of equality itself. In addition, this is also a form of resistance to patriarchal values, which are still very strong in Indonesia, so it is deemed necessary to bring up other spaces that support the values of equality and humanity within the scope of Islam in particular.

KUPI had done a lot of social and humanitarian work. Even before KUPI came into existence, the author felt it was not strange when he used to call the ulama a man because this has become a very strong culture in our country. However, after examining gender equality, the author realizes that Islam in its actualization is still very minimal to be considered successful in realizing gender equality itself.

The KUPI movement has directly become a form of fresh air for Islam because, in the meaning of both the verses of the Koran and the Hadith that KUPI guarantees, they have many gender-fair values. Thus, in countering the patriarchal culture, which is still very strong in Indonesia, KUPI's struggle is still very long and will face various challenges.

In addition, what needs to be understood is that Ulama is the owner of a significant share in the spread of Islam. Thus, to have messages and invitations to goodness based on the value of gender justice is something that Ulama should own. Because the author realizes that there are still many Ulama in Indonesia who do not have a perspective on gender justice, the role of KUPI is there, spreading Islamic messages based on gender justice. (Ma'arif, 2003).

\subsection{Empowering Women Through Gender Equality}

Women's empowerment is a process of awareness and capacity building for greater participation such as breadth, supervision, and decision-making as well as information actions that lead to the realization of greater equality between women and men (Ma'arif, Malang: 189) According to Qasim Amin, men and women have similarities, both in terms of body parts, senses, thoughts, and all desires. The similarities are because both of them are human - the difference lies only in the degree required by the different types.

Suppose men exceed women in physical strength and reasoning abilities. In that case, it is due to conditions so far that require only men to work and think, while women are prohibited from working and thinking so that they remain in a weak condition (Haramain, 2019, Vol. 5, No. 2: 224) Da'wah as an empowerment activity, especially in the aspect of gender equality, can be interpreted as a vision to support a more progressive dimension of women's repositioning. Da'wah activities are usually quite massive, but judging from the material aspect of da'wah, most of them are still oriented to the topics of the hereafter, not covering social-contextual aspects (Sa'dan, 2016, Vol. 12, No. 1: 37).

The involvement of KUPI (Congress of Indonesian Women Ulama) in realizing gender equality in the Islamic religious environment, in particular, has become one of the crucial highlights that 
scholarship on ulema is a science that can be possessed by all human beings, in this case, both men and women. In KUPI circles, the value of empowering women who are categorized as ulama is a form of embodiment of gender equality (Wardah, 2017).

\section{CONCLUSION}

The patriarchal culture is still powerful in Indonesia, where most of the population is religious, especially Islam, so it is challenging to realize values and convey Islamic messages that are genderjust. In particular, it is about the ulama, who, until now, many still think that a cleric is only from men. The presence of female ulama in Indonesia breaks this fact that, in reality, the understanding of the ulema itself departs from the source of the verses of the Qur'an. There is no requirement that a cleric must be male. Hence, the presence of female clerics is part of the form of the struggle to realize and convey gender-just Islamic values and messages. Through the Congress of Women Ulama in Indonesia (KUPI), the presence of women ulama needs to be acknowledged. That indeed, women have the potential of humanity, which is also owned by men. So, to convey the message of Islam that is gender-just, it is necessary to convey the message to people, in this case, scholars who understand gender justice.

\section{REFERENCES}

Ermagusti. (2011). Prinsip Kesetaraan Gender Islam. Jurnal IImiah Kajian Gender. diakses pada Minggu 4 Juli 2021 pukul 22.40 WIB, dari laman https://www.researchgate.net/publication/274277035_PRINSIP_KESETARAAN_GENDER_DALAM_ISL AM.

Haramain, Muhammad. (2019). Dakwah Pemberdayaan Perempuan: Telaah Pemikiran Qasim Amin Tentang Kesetaraan Gender, "Jurnal Pemikiran Islam", Vol. 5, No.2.

Juhari. (2018). Pencitraan Ulama Dalam Al-Quran. Jurnal Peurawi, Vol. 1, No. 2.

Kasmawati. (2013). Gender dalam Perspektif Islam. Jurnal Sipakalebi, Vol. 1, No. 1.

Ma'arif, Syafi'i. (2003). Pembangunan dalam Perspektif Gender. Malang: UMM Press.

Muhammad, Husein. (2020). Perempuan Ulama di Atas Panggung Sejarah: Yogyakarta.

Rusjdi, Ali, Muhammad. (2003). Revitalisasi Syariat Islam di Aceh: Problem, Solusi, dan Implementasi. Logos: Jakarta dan Ar-Raniry Press Banda Aceh.

Sa'dan, Masthuriyah. (2016). Rekonstruksi Materi Dakwah untuk Pemberdayaan Perempuan: Perspektif Teologi Feminisme. Jurnal Harkat: Media Komunikasi Gender", Vol. 12, No. 1.

Wardah, Fathiyah. 2017. Kongres Ulama Perempuan Indonesia Hasilkan Tiga Fatwa. Diakses pada Sabtu, 4 Desember 2021 pukul 14.03 WIB, dari https://www.voaindonesia.com/a/kongresulama-perempuan-indonesia-hasilkan-3-fatwa-/4005416.html.

Zahara, Adibah, Ida. (2019). Kontribusi Ulama Perempuan dalam Perkembangan Islam di Nusantara, "Jurnal Studi dan Sosial", Vol. 6, No. 2. 